\author{
Andrija Petrović \\ Research Intern \\ University of Belgrade \\ Faculty of Mechanical Engineering \\ Department of Process Engineering \\ Miloš Lomović \\ Doctoral Student \\ University of Belgrade \\ Faculty of Mechanical Engineering \\ Department of Automatic Control \\ Milan Ristanović \\ Associate Professor \\ University of Belgrade \\ Faculty of Mechanical Engineering \\ Department of Automatic Control \\ Aleksandar Petrović \\ Full Professor \\ University of Belgrade \\ Faculty of Mechanical Engineering \\ Department of Process Engineering
}

\section{Modelling, Simulation and Control of Desalination Plant with a Liquid Jet Ejector}

In this paper, modelling, simulation and control of water desalination plant is presented. The desalination plant is based on vapour compression method acquired utilizing a liquid jet ejector. Nonlinear steady-state model is developed in order to verify simplified dynamic model for control purposes. Furthermore, to design PI controller capable of guiding the system through desired states under the influence of disturbances, the linearized model of the plant has been developed and verified applying the nonlinear dynamical model. It is shown that presented approach can deliver satisfying model and tracking results.

Keywords: Water desalination plant, geothermal energy, Liquid jet vacuum ejector, Process control, PI regulator.

\section{INTRODUCTION}

Many methods for desalination have been developed, such as reverse osmosis (RO), vapour compression, distillation and electro-dialysis. In the last years, significant advances in technology have allowed essential improvements in desalination quality and general reduction of costs. The rapid growth of population and industry in all areas of the world imposes the need for further improvements in the desalinated water production process. To further improve existing methods the suitable plant controls system is necessary.

Reverse osmosis has been the most utilized method for desalination since it has several advantages over other methods. The main advantages are its simple design, lower maintenance costs, easier debottlenecking, simultaneous removal of both organic and inorganic impurities, low discharge in the purge stream, and energy savings, [1].

Significant improvements in the technology of desalination are not observed in the last period, so more and more attention is paid to the optimization of thermodynamic parameters of the existing cycle to obtain lower investment, operational costs and less impact on the environment [2] and [3].

Although, RO is the most used method when it comes to utilization of geothermal energy it is justified to use vapour compression methods. Utilization of geothermal energy for desalination can be achieved by direct evaporation of the hot water, which emerges on the surface (hot springs), or indirectly, using geothermal energy for heating and evaporating water, [4] and [5]. Significant work in modeling of thermal vapour compression desalination plants with ejector is done in [6] and [7].

Received: December 2017, Accepted: March 2018

Correspondence to: Andrija Petrović

Faculty of Mechanical Engineering,

Kraljice Marije 16, 11120 Belgrade 35, Serbia

E-mail: aapetrovic@mas.bg.ac.rs

doi:10.5937/fmet1804530P

(C) Faculty of Mechanical Engineering, Belgrade. All rights reserved
This paper has a goal to show an approach to simulation and control of the desalination plant based on a vapour compression with a liquid jet vacuum ejector. The desalination plant under consideration is supplied with a geothermal water. Comprehensive steady-state model has been developed and simulated. Moreover, for control purposes, dynamical model of the plant has been developed and linearized around chosen operating point. Furthermore, the dynamical model is verified by comparison with the results of the steady-state simulation. According to the derived dynamic model of the plant, and further model linearization, the PI controller is tuned.

\section{INSTALATION DESCRIPTION AND PROBLEM STATEMENT}

The desalination plant under consideration is shown in Fig 1. Vessel P1 has been supplied with geothermal water from hot springs with an average temperature of $73.5^{\circ} \mathrm{C}$. The liquid jet vacuum ejector E1 is utilized to maintain the pressure in P1 lower than the pressure corresponding to the evaporation temperature of the inlet water. The saturated steam is entrained in the ejector E1. Due to low entrained ratio, the steam is completely condensed in the ejector. Therefore, to hold the constant water temperature $t_{104}$ at the steady-state regime the heat exchanger HE1 is utilized. The inlet and the outlet temperature of the cold fluid (river water) in HE1 are assumed to be equal and constant. The purpose of pump PU2 is to drain boiled water and to maintain a constant liquid level in the vessel P1. Pump PU1 together with valve $\mathrm{V} 1$ are controlling the pressure in the vessel P1 indirectly.

Pump PU1 is controlled by the frequency converter, while V1 is control valve. Level transmitter LT-P1 have been mounted at the P1. The pressure transmitter PT-P1 measures pressure in the $\mathrm{P} 1$.

Generally, the pump for motive fluid does not have the controller. Thus, it operates at a fixed frequency of $50 \mathrm{~Hz}$ which is provided by the power network. 
Additionally, there is no guarantee that the system shall have the maximum effectiveness of its capacity for different values of inlet mass flow rates and temperatures (state 101).

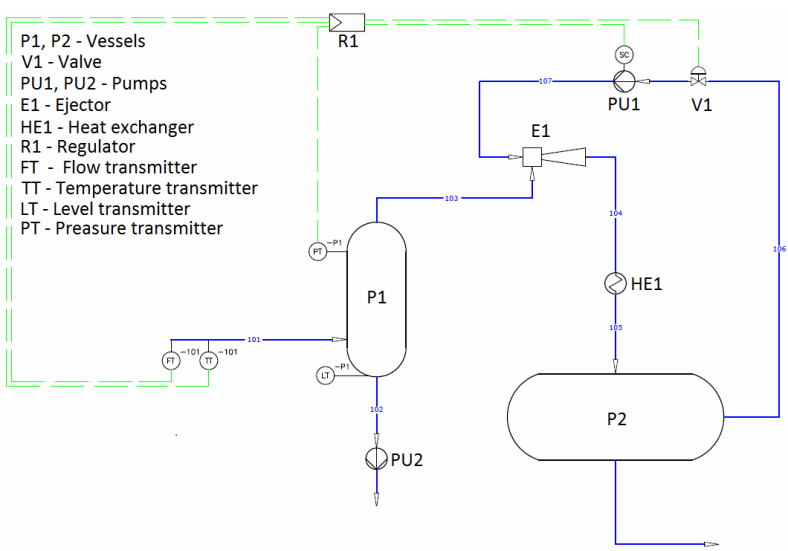

Figure 1. A piping and instrumentation diagram and control structure of water desalination plant.

Controller R1 controls the pump PU1 frequency and at the same time the hydraulic resistance of the valve V1.

To simplify the problem, certain reasonable assumptions have been introduced. The water level in P1 is constant and heat loss in the vessel P2 is negligible, so $t_{104}=t_{106}$.

\section{STEADY-STATE MODELING AND SIMULATION}

\subsection{Modelling}

The adopted geometric dimensions of the plant are presented in Table 1, where $A_{\text {nozzle }}$ is primary motive nozzle cross-section area; $A_{\text {chamber }}$ is ejector mixing chamber cross-section; $L$ is pipe length between pump and ejector inlet; $S_{H E}$ is heat transfer area; $D$ is pipe diameter and $d_{s}$ is the diameter of heat exchanger tube.

Table 1. Geometric sizes of individual parts of plant equipment

\begin{tabular}{|c|c|c|c|c|c|}
\hline $\begin{array}{c}A_{\text {nozzle }} \\
{\left[\mathrm{m}^{2}\right]}\end{array}$ & $\begin{array}{c}A_{\text {nozzle }} \\
A_{\text {chamber }} \\
{[-]}\end{array}$ & $\begin{array}{c}L \\
{[\mathrm{~m}]}\end{array}$ & $\begin{array}{c}S_{H E} \\
{\left[\mathrm{~m}^{2}\right]}\end{array}$ & $\begin{array}{c}D \\
{[\mathrm{~m}]}\end{array}$ & $\begin{array}{c}d_{s} \\
{[\mathrm{~m}]}\end{array}$ \\
\hline 0.0038 & 0.19183 & 10 & 10 & $\begin{array}{c}0.258 \\
8\end{array}$ & 0.04 \\
\hline
\end{tabular}

Due to the change of seasons, the temperature and mass flow rates of mineral water are varying. During the winter a temperature of the geothermal water is decreasing to $65^{\circ} \mathrm{C}$, while in the average summer temperature is around $82^{\circ} \mathrm{C}$. Similarly, the mass flow rates are varying in the range from 0,05 to $1 \mathrm{~kg} / \mathrm{s}$. The goal is to simulate the system in consideration for different values of operating point of the pump (frequency) and position of the control valve (hydraulic resistance) in order to obtain the nonlinear model.

The simulation constraints are given in the form of physical limitations concerning the frequency range from $15 \mathrm{~Hz}$ to $50 \mathrm{~Hz}$ and the range of valve hydraulic resistance 4,66 to 300. An additional limitation has been introduced regarding the cavitation of the ejector operation represented by the equation (1):

$$
p_{103}<p_{107, \text { cavitation }}+1500 \mathrm{~Pa},
$$

where $p_{107, \text { cavitation }}$ is saturation pressure of operating water for temperature $t_{107}$.

Simulations were performed for an average temperature of $73.5^{\circ} \mathrm{C}$ and the mass flow rate has been varied from $0,05 \mathrm{~kg} / \mathrm{s}$ to $1 \mathrm{~kg} / \mathrm{s}$, with a step of $0.05 \mathrm{~kg} / \mathrm{s}$. Steady-state simulation has been made in accordance with the equations the mass and energy balances of each individual part of the plant.

Based on calculations for the individual parts of the plant, Table 1, and constant thermophysical states of water desalination plant, the following pump is chosen: Grundfos NK 125-250/222 A2-FAE-BAQE. Pump characteristic is shown in Fig 2.

Data obtained from the manufacturer is given as a discrete set of values and only for one frequency values. The data are fitted for a variety of frequencies values by linear regression (Furrier 2. order method) evaluated as:

$$
\begin{aligned}
y & =a_{0}+a_{1} \cos (\omega x)+b_{1} \sin (\omega x)+ \\
& +a_{2} \cos (2 \omega x)+b_{2} \sin (2 \omega x),
\end{aligned}
$$

where $a_{0}=47.31, a_{1}=10.711, a_{2}=0.4696, b_{1}=15.27$, $b_{2}=0.2751$ and $\omega=0.004719$.

The specter of pump characteristics for different frequencies, which drives the pump, is given in Fig 2. Due to motor's frequency limitation and cavitation, the pump cannot work at every point represented in the diagram. Therefore minimal and maximal possible values are labeled as $\dot{V}_{\min }$ and $\dot{V}_{\max }$.

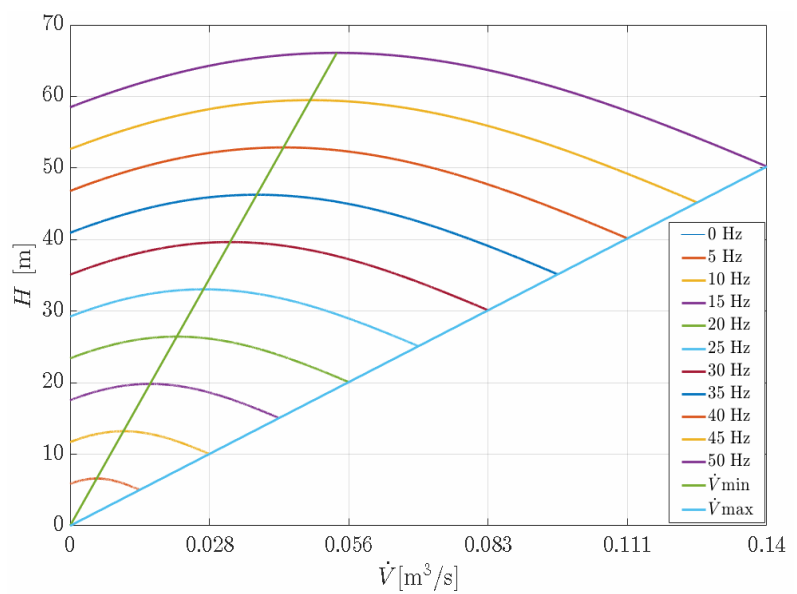

Figure 2. Fitted pump characteristic for different values of frequencies.

Simulation equations of the liquid jet vacuum ejector, equations (3) and (4) are given in accordance with the semi-experimental equations shown in [8].

$$
\begin{aligned}
q & =\dot{m}_{101} \cdot \frac{\left(h_{101}-h_{102}\right)}{\left(h_{103}-h_{102}\right)} \cdot \frac{1}{\rho_{103} \cdot V_{107}}, \\
& \frac{p_{104}-p_{103}}{p_{107}-p_{103}}=1.75 \cdot \frac{A_{\text {nozzle }}}{A_{\text {chamber }}}- \\
& -1.07 \cdot\left(\frac{A_{\text {nozzle }}}{A_{\text {chambr }}}\right)^{2} \cdot\left(1+\frac{q}{15}\right)^{2}
\end{aligned}
$$


where $\left(\dot{V}_{107}, p_{107}\right)=F\left(f, \zeta_{v}\right)$.

The design of heat exchanger is based on the energy balance equation and the system of equations for calculation of the overall heat transfer coefficient as a basis for using the NTU method, [9]. The flow rate of the cold fluid (river water) is assumed to be infinite, so there will be no change of the cold fluid temperature (it is equal to the ambient temperature) - consequently $R=\infty$. By adopting the expression for the mean value of the Nusselt numbers, on the desalinated water side, equation (5) [10], and on the river water side, equation (6) [11], the desired temperature $t_{105}$ can be determined based on the adopted surface and given states $t_{104}, p_{104}, t_{a m b}$.

$$
\begin{gathered}
N u_{D}=0.027 \cdot \operatorname{Re}_{D} \cdot \operatorname{Pr}^{\frac{1}{3}} \cdot\left(\frac{\mu}{\mu_{s}}\right)^{0.14}, \\
N u_{\text {river }}=a_{1} \cdot\left(1.33 \cdot \frac{d_{s}}{s_{c}}\right)^{a} \cdot \operatorname{Re}_{r \text { river }}^{a_{2}} \cdot \operatorname{Pr}^{\frac{1}{3}} \cdot \phi_{t},
\end{gathered}
$$

where $R e$ is the Reynolds number; $P r$ is the Prandtl number; $N u_{r i v e r}, N u_{D}$ are the Nusselt numbers of the cold fluid (river) and hot fluid (desalinated water), respectively; $\phi_{t}=\left(T / T_{w}\right)^{0.25}$ is the correction factor; $a_{1}$, $a_{2}$ are experimental parameters; $d_{s}$ is the external pipe cross-section; $s_{c}$ is the distance between the pipes.

\subsection{Simulation results}

The results of the plant simulation for different values of mass flow rates at the plant's inlet $\left(\dot{m}_{101}\right)$ and temperatures $\left(t_{101}\right)$ are presented in Figs. 3, 4 and 5. It can be observed (Fig. 3) that on the trajectory, vapour temperature of entrained steam $\left(t_{103}\right)$ is increasing with the increase of $\dot{m}_{101}$ and $t_{101}$. Also, the mass flow rate of the desalinated water $\dot{m}_{103}$ (Fig. 4) along with the motive water pressure $p_{107}$ and the mass flow rate $\dot{m}_{107}$ (Figs. 4 and 5, respectively) are increasing with the increase of the $\dot{m}_{101}$ and $t_{101}$.

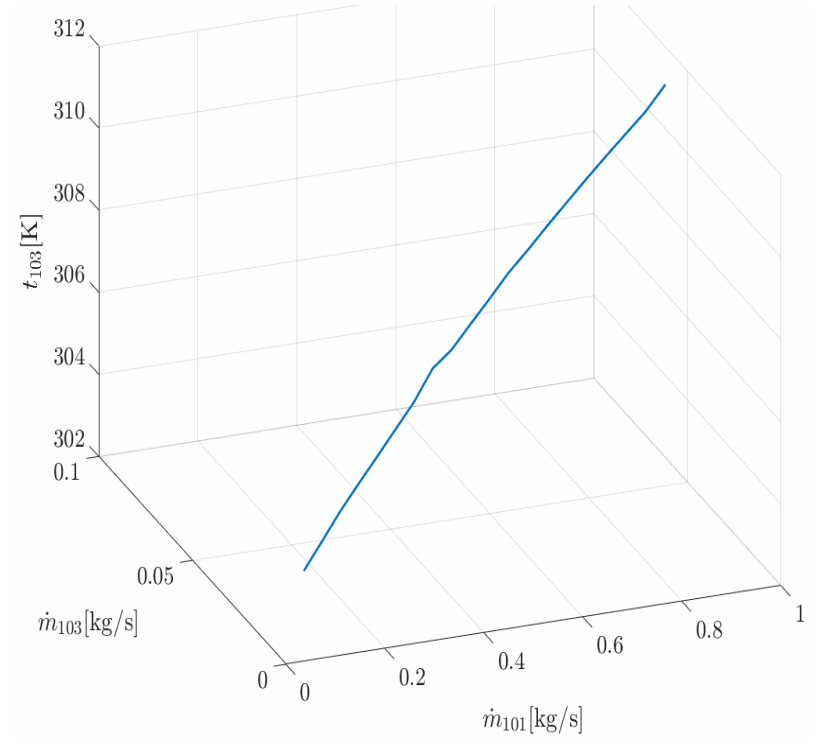

Figure 3. The trajectory of the plant at $t_{101}=73.5^{\circ} \mathrm{C}$.

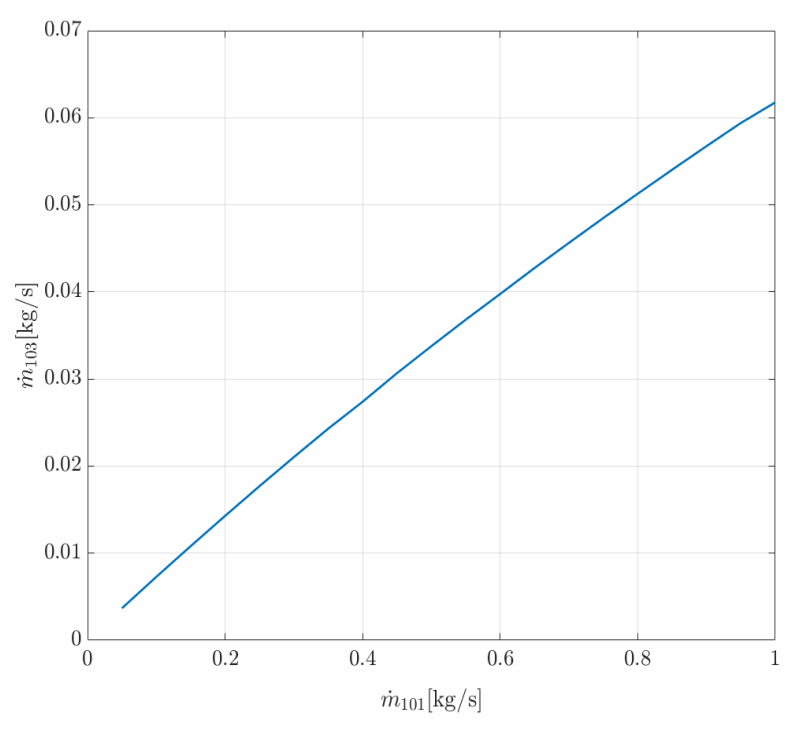

Figure 4. Dependence of $\dot{m}_{103}$ with respect to mass flow rate $\dot{m}_{101}$.

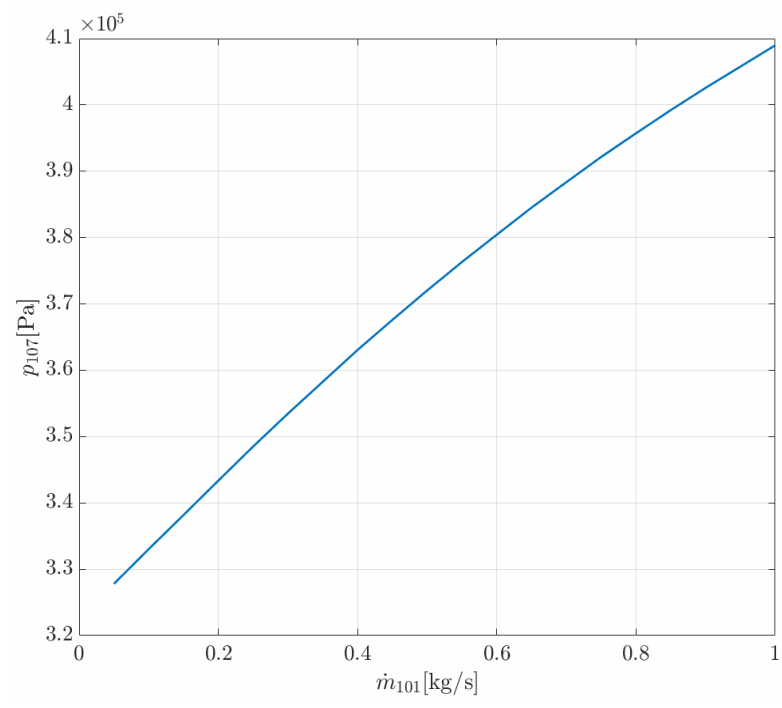

Figure 5. Dependence of $p_{107}$ with respect to mass flow rate $\dot{m}_{101}$

\section{CONTROL SYSTEM DESIGN}

\subsection{Modelling and simulation}

Acquiring a suitable dynamical model for the control purposes requires certain assumptions. Reasonable assumptions are introduced as follows:

- The specific heat capacities of liquid at constant pressure $\left(c_{p}\right)$ and at constant volume $\left(c_{v}\right)$ are constant;

- Volumes occupied by vapour $\left(V_{V}\right)$ and liquid $\left(V_{L}\right)$ are constant;

- Steady-state conditions of liquid jet vacuum ejector are assumed;

- Mass accumulation in vessel V1 is negligible;

- Water density is constant;

- Water vapour is saturated at the position 103, whereas liquid is boiled at the position 102 such that, $p_{102}=p_{103}$ and $t_{102}=t_{103}$;

- Friction loss in the instalation is neglected; 
- Heat loss in the surrounding is neglected.

The dynamical model has been developed using mass balance for the vessel P1:

$$
\dot{m}_{101}=\dot{m}_{102}+\dot{m}_{103}
$$

Additionaly, energy balance for the vessel P1 is expressed as:

$$
\begin{gathered}
\frac{d U}{d t}=\dot{m}_{101} \cdot h_{101}-\dot{m}_{102} \cdot h_{102}-\dot{m}_{103} \cdot h_{103} \\
\frac{d}{d t}\left(\rho_{L} \cdot V_{L} \cdot c_{v L} \cdot t_{102}+\rho_{V} \cdot V_{V}\left(c_{v L} \cdot t_{102}+\Delta h_{L A T}\right)\right)= \\
=\dot{m}_{101} \cdot c_{p L} \cdot t_{101}-\dot{m}_{102} \cdot c_{p L} \cdot t_{102}- \\
-\dot{m}_{103}\left(c_{p L} \cdot t_{102}+\Delta h_{L A T}\right)
\end{gathered}
$$

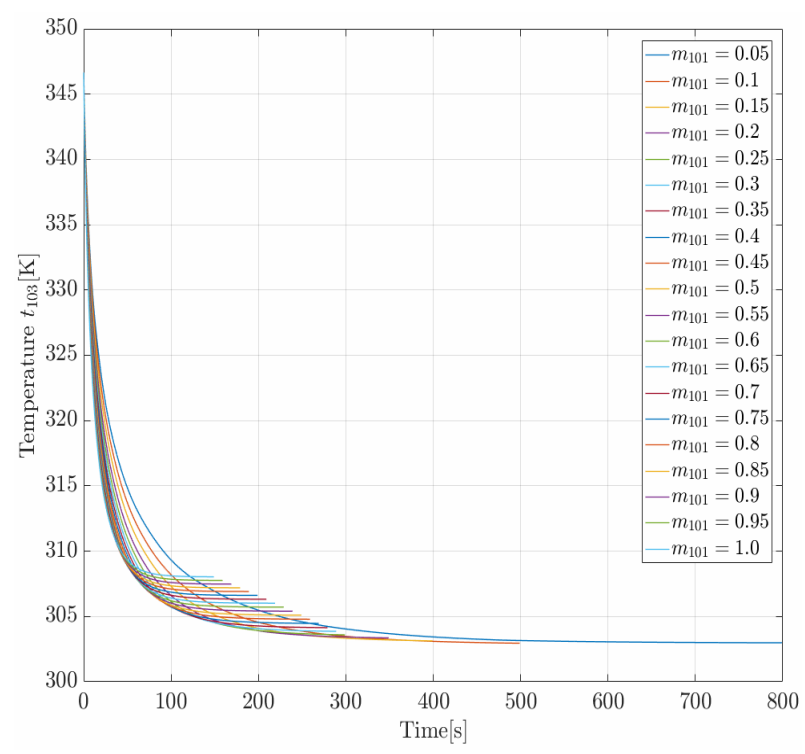

Figure 6. Step responses of nonlinear plant model for some operating point initiated with chosen values of $f$ and $\zeta_{v}$.

Table 2. Values of $\boldsymbol{f}$ and $\zeta_{v}$ for different inlet mass flow rates, $\dot{m}_{101}$ when $t_{101}=73.5^{\circ} \mathrm{C}$.

\begin{tabular}{|c|c|c|}
\hline$\dot{m}_{101}[\mathrm{Kg} / \mathrm{s}]$ & $f[\mathrm{~Hz}]$ & $\zeta_{v}[-]$ \\
\hline 0.05 & 36.34 & 86.10 \\
\hline 0.10 & 35.29 & 69.29 \\
\hline 0.15 & 35.57 & 66.95 \\
\hline 0.20 & 42.27 & 129.34 \\
\hline & & \\
\hline 0.25 & 42.58 & 126.50 \\
\hline 0.30 & 39.27 & 88.81 \\
\hline 0.35 & 36.62 & 58.03 \\
\hline 0.40 & 36.87 & 56.10 \\
\hline 0.45 & 40.13 & 83.07 \\
\hline 0.50 & 44.00 & 114.58 \\
\hline 0.55 & 38.12 & 56.15 \\
\hline 0.60 & 37.78 & 49.47 \\
\hline 0.65 & 37.85 & 46.66 \\
\hline 0.70 & 38.34 & 47.98 \\
\hline 0.75 & 41.37 & 71.97 \\
\hline 0.80 & 38.58 & 44.18 \\
\hline 0.85 & 38.80 & 43.38 \\
\hline 0.90 & 38.92 & 41.82 \\
\hline 0.95 & 39.01 & 40.14 \\
\hline 1.00 & 46.14 & 98.22 \\
\hline
\end{tabular}

The simulation has been done using a combination of the equations (7) and (8). Initial conditions were $t_{102}^{0}=t_{101}$, and the plant is considered to be in steadystate with PU1 turned off. The values of $f$ and $\zeta_{v}$ used in the simulation are chosen by experience and can be seen in Table 2. Numerical simulation of the nonlinear mathematical model are presented in Fig. 6.

\subsection{Linearization}

In order to tune PI controller gains the linear model around operational point is necessary. Linearization is carried out using polynomial curve fitting with least squares error method for every nonlinear simulation. The results of linearisation are shown in Fig 7.

Linearization results have been verified by comparing nonlinear and linearised step responses. The comparison is shown only for three operating points, Fig 8. This result is considered to be accurate enough to calculate controller parameters. Furthermore, in Table 3 the linearised models of the plant have been presented in the form of transfer functions.

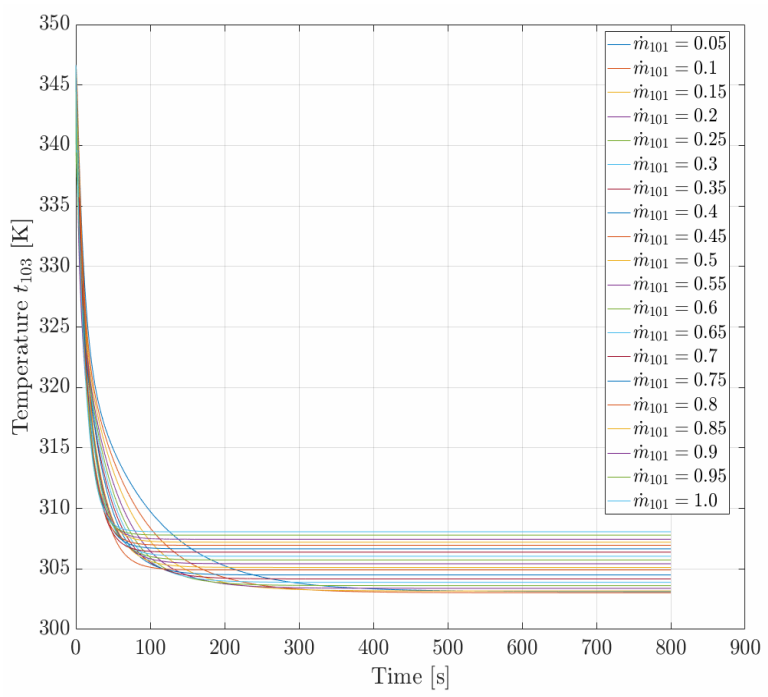

Figure 7. Step responses linearized plant model for some operating points initiated with chosen values of $f$ and $\zeta_{v}$.

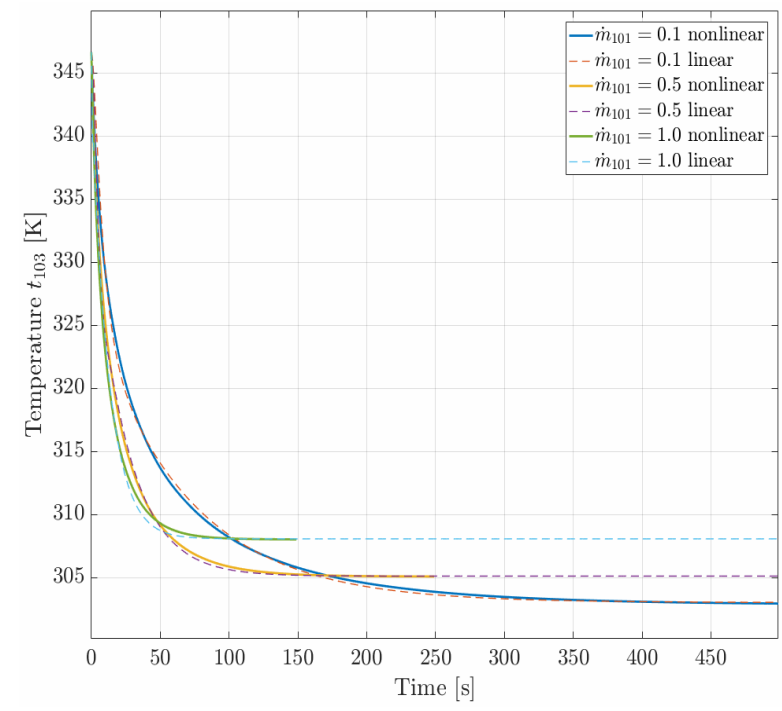

Figure 8. Step responses of nonlinear and linearized plant model for three operating points initiated with chosen values of $f$ and $\zeta_{v}$. 
Table 3. Transfer functions of the linearized plant for three operating points.

\begin{tabular}{|c|c|}
\hline Linearization point & Transfer function $G_{p}(s)$ \\
\hline$\dot{m}_{101}=0.1 \mathrm{~kg} / \mathrm{s}$ & $\frac{-1.93 \mathrm{~s}-0.051}{1.021 s^{3}+0.73 s^{2}+0.09 s+0.001}$ \\
\hline$\dot{m}_{101}=0.5 \mathrm{~kg} / \mathrm{s}$ & $\frac{-2.27 \mathrm{~s}-0.24}{0.82 s^{3}+0.51 s^{2}+0.16 s+0.006}$ \\
\hline$\dot{m}_{101}=1.0 \mathrm{~kg} / \mathrm{s}$ & $\frac{-2.53 \mathrm{~s}-2.10}{0.047 s^{3}+0.11 s^{2}+0.70 s+0.05}$ \\
\hline
\end{tabular}

\subsection{Control law}

The controller R1, Fig. 1, controls two manipulated variables. In this paper, the controller has been designed to control the frequency of PU1, while hydraulic resistance V1 was controlled by look-up table formed from Table 2 .

From Eq. (8) and nonlinear simulation results presented in Fig. 6, it can be determined that plant is stable for every input value. However, the time constants and deviation from the desired states of the plant are too high. Therefore, in order to improve systems characteristics Proportional Integral (PI) controller has been adopted. Proportional and integral gains of the controller have been added to lower the time constant and error, respectively, [12]. The mentioned controller has the following control law:

$$
\begin{gathered}
u(t)=K_{p} e(t)+K_{i} \int_{0}^{t} e(\tau) d \tau, \\
e(t)=r(t)-y(t)
\end{gathered}
$$

where $u(t)$ is control signal; $e(t)$ is error signal; $K_{p}$ and $K_{i}$ are proportional and integral gains respectively, and $r(t)$ is reference signal.

Parameters of the PI are calculated using pole placement method, as described in [12], with respect to minimizing overshot and settling time in order to avoid cavitational regime of the ejector. Controller are tuned using nonlinear dynamical simulation to obtain maximal performances: $K_{p}=-2.24$ and $K_{i}=-0.58$.

\section{SIMULATION RESULTS}

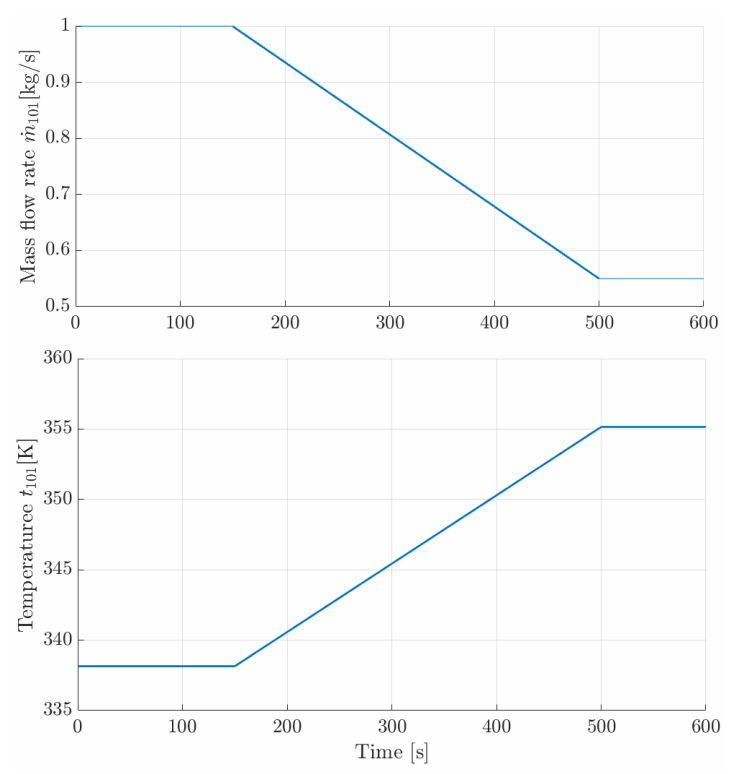

Figure 9. Changing of input mass flow rate, $\dot{m}_{101}$, and temperature, $t_{101}$, during $600 \mathrm{~s}$ of simulation.
The simulation has been performed for initial conditions $t_{103}^{0}=346.65 \mathrm{~K}$ Changes in the disturbances was chosen to simulate a worst-case scenario in short period of time, where mass flow rate, $\dot{m}_{101}$, drops and temperature, $t_{101}$, rises over a period of $350 \mathrm{~s}$, as it is shown in Fig. 9.

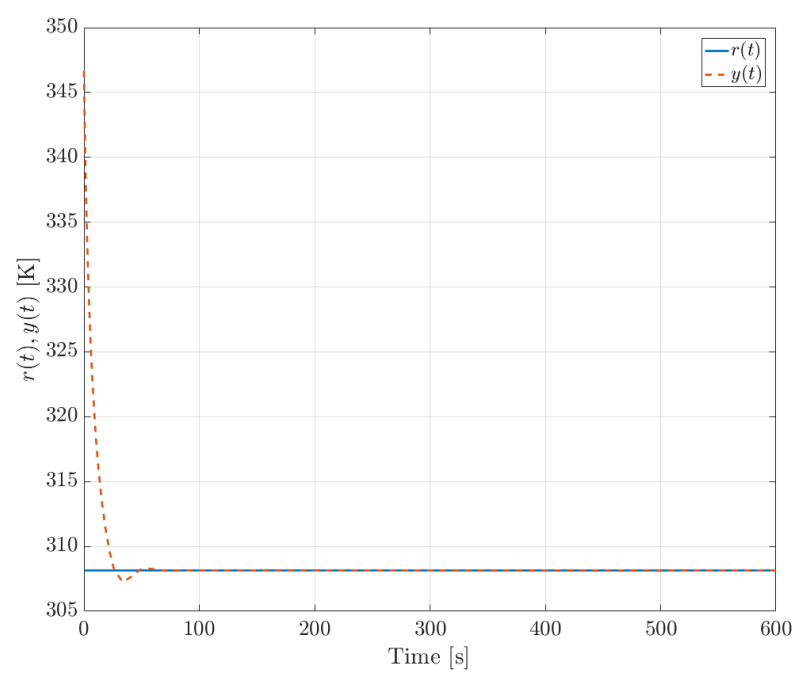

Figure 10. Simulation of the nonlinear system controlled by PI controller under the influence of disturbances, and with the initial condition $t_{102}^{0}=346.65 \mathrm{~K}$.

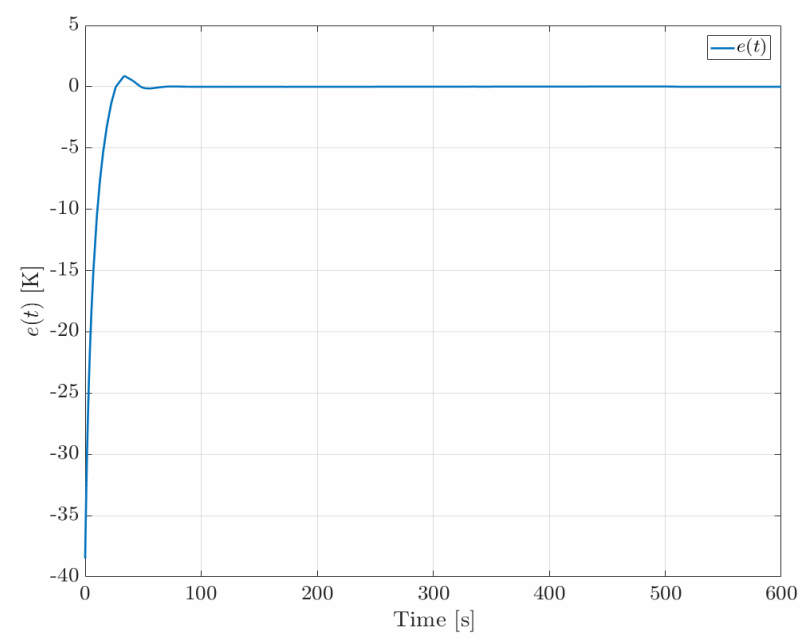

Figure 11. Error signal, $e(t)$, generated during simulation.

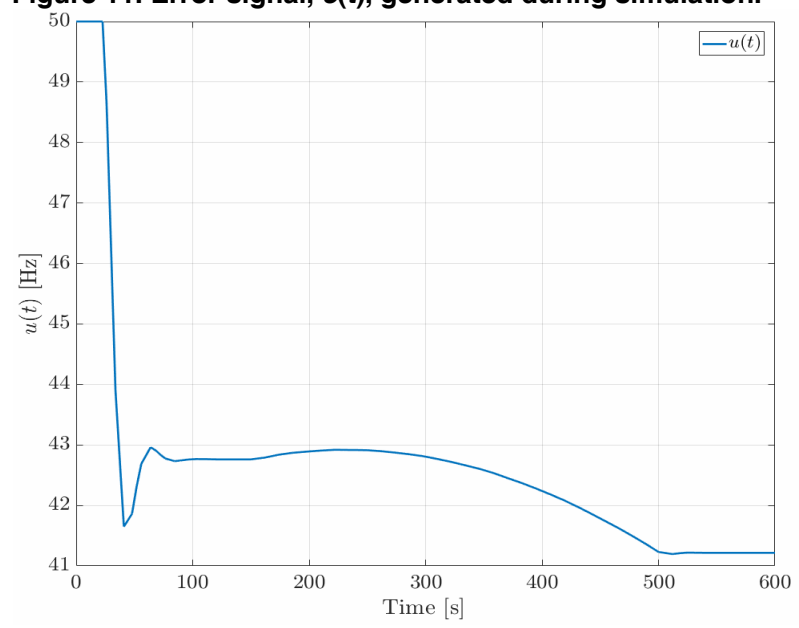

Figure 12. Control signal, $u(t)$, generated during simulation.

Results of control simulation with PI controller are given in Fig. 10. Although, disturbances are taking 
place after $150 \mathrm{~s}$ of simulation the controller can stabilize the system around desired value with the minimal error, Fig. 11.

In Fig. 12 can be seen that during all time of simulation the control signal, $u(t)$, was within the acceptable boundaries.

\section{CONCLUSION}

An approach for simulation and control of desalination plant with a liquid jet ejector is presented. The comprehensive steady state simulation of the plant is developed. In addition, based on the presented assumptions dynamical model is evaulated and verified with the steady state simulations results.

Moreover, in order to guide the plant through desired thermodynamic states PI controller was designed. It can be seen that this type of the controller can hold the system around desired state even during the effect of disturbances. The presented paper enables further research in control systems and optimization that can improve rentability and sustainability of plant.

In further work, the multi-objective optimization (NSGA-II) of the plant will be introduced similarly as it was done in [13]. Further, controller optimization might be carried out in order to achieve better performances as it is shown in [14].

\section{REFERENCES}

[1] HO, W.S. and Sirkar, K.K.: Membrane handbook, Springer Science \& Business Media, pp. 263-355, 2001.

[2] Vince, F., Marechal, F., Aoustin, E., and Breant, P.: Multi-objective optimization of $R O$ desalination plants. Desalination, 222(1-3), pp. 96-118, 2008.

[3] Ahmetovic, E., Grossmannb, I.E., Kravanjac, Z. and Ibric, N.: Simple additive weighting approach to personnel selection problem, International Journal of Innovation, Management and Technology, 1(5):511, 2010.

[4] Al-Garni, A.Z., Abdelrahman, W.G.: Water desalination system using geothermal energy, US Patent 9,289,696, Mar. 22, 2016.

[5] Gude, V.G.: Geothermal source potential for water desalination - current status and future perspective, Renewable and Sustainable Energy Reviews, 57:1038-1065, 2016.

[6] El-Dessouky, H.T., Ettouney, H.M., Al-Juwayhel, F.: Multiple effect evaporation-vapour compression desalination processes, Chemical Engineering Research and Design 78, no. 4 (2000): 662-676.

[7] Park, Il-Seok et al.: Design and application of thermal vapor compressor for multi-effect desalination plant, Desalination 182, no. 1-3 (2005): 199-208.

[8] Sokolov, E.: Flow machines (in Russian), Moskva Energoatomizdat, Moscow, 1989.

[9] Shah, R.K. and Sekulic, D.P.: Fundamentals of heat exchanger design, John Wiley \& Sons, 2003.

[10]Bergman, T.L., Incropera, F.P.: Fundamentals of heat and mass transfer, John Wiley \& Sons, 2016.
[11] Jacimovic, B. and Genic, S.: Thermal operations and apparatus, Part 1: Recuperative heat exchangers, Faculty of Mechanical Engineering, Belgrade, 2004.

[12] Åström, K., Hägglund, T.: PID Controllers: Theory, Design and Tuning, Instrument Society of America, Research Triangle Park, NC, 1995.

[13] Rajković, M., Zrnić, N., Kosanić, N., Borovinšek, M., Lerher, T.: A Multi-Objective Optimization model for minimizing costs, traveling time and $\mathrm{CO} 2$ emission in an $A S / R S$. FME Transactions, Scientific Journal published by the Faculty of Mechanical Engineering in Belgrade, vol.45, pp. 620-629, 2017.

[14] Nagarkar, P.M., Vikhe Patil, J.G.: Multi-Objective Optimization of LQR Control Quarter Car Suspension System using Genetic Algorithm. FME Transactions, Scientific Journal published by the Faculty of Mechanical Engineering in Belgrade, vol.44, pp. 187-196, 2016.

\section{NOMENCLATURE}

$\begin{array}{ll}t & \text { temperature }[\mathrm{K}] \\ p & \text { pressure }[\mathrm{Pa}] \\ h & \text { enthalpy }[\mathrm{J}] \\ \dot{m} & \text { mass flow rate }[\mathrm{kg} / \mathrm{s}] \\ \dot{V} & \text { volumetric flow rate }\left[\mathrm{m}^{3} / \mathrm{s}\right] \\ & \text { specific heat capacity at constant pressure } \\ c_{p} & {[\mathrm{~J} / \text { kgK }]} \\ & \text { specific heat capacity at constant volume } \\ c_{v} & {[\mathrm{~J} / \text { kgK }]} \\ A & \text { cross-section area }\left[\mathrm{m}^{2}\right] \\ L & \text { pipe length between pump and ejector inlet } \\ D & {[\text { pipe diameter }[\mathrm{m}]} \\ d_{s} & \text { the diameter of heat exchanger tube }[\mathrm{m}] \\ S_{H E} & \text { heat transfer area }\left[\mathrm{m}^{2}\right] \\ R e & \text { Reynolds number }[-] \\ P r & \text { Prandtl number }[-] \\ N u & \text { Nusselt number }[-] \\ f & \text { frequency }[\mathrm{Hz}] \\ U & \text { Internal energy }[\mathrm{J}] \\ V & \text { volume }\left[\mathrm{m}^{3}\right]\end{array}$

\section{Greek symbols}

$\begin{array}{ll}\rho & \text { Density }\left[\mathrm{kg} / \mathrm{m}^{3}\right] \\ \zeta_{v} & \text { hydraulic resistance of the valve [-] } \\ \tau & \text { time of integration } \\ \phi_{t} & \text { correction factor }\end{array}$

\section{Subscripts}

$\begin{array}{cl}V & \text { vapour } \\ L & \text { liquid } \\ w & \text { water } \\ L A T & \text { latent } \\ \text { nozzle } & \text { nozzle } \\ \text { chamber } & \text { chamber }\end{array}$




\section{МОДЕЛОВАЫЕ СИМУЛАЦИЈА И УПРАВЉАЊЕ ПОСТРОЈЕЫА ЗА ДЕСАЛИНИЗАЦИЈУ ВОДЕ}

Ан. Петровић, М. Ломовић, М. Ристановић,

\section{Ал. Петровић}

У раду је приказан метод моделовања, симулације и управљања постројења за десалинизацију воде. Постројење за десалинизацију воде спада у класу постројења које упаравају слану воду корићењем водено-парног ејектора. У циљу валидације резултата симулације динамичког модела, развијеног у циљу управљања, резултати стационарне симулације постројења су коришћени. Додатно развијен је PI контролер који доводи систем до жељених стања при утицају поремећаја. Линеаризовани модел постројења је верфикован помоћу нелинеарног динамичког модела. Показано је да наведени приступ даје задовољавајуће резултате. 